\title{
Proposal of Optimization of Depth Values in Wet Gap Crossing Military Operations
}

\author{
M. Sedláček ${ }^{1 *}$ and F. Dohnal ${ }^{2}$ \\ ${ }^{1}$ Department of Engineer Support, Faculty of Military Leadership, \\ University of Defence in Brno, Czech Republic \\ ${ }^{2}$ Department of Military Geography and Meteorology, Faculty of Military Technology, \\ University of Defence in Brno, Czech Republic
}

The manuscript was received on 11 May 2020 and was accepted after revision for publication as technical information on 6 March 2021.

\begin{abstract}
:
The paper deals with the proposal of the optimization of values at depths of wet gaps in order to make the selection of the area for wet gap crossing, which is planned in the Task Force staff, more effective. The main contribution of the article is a comparison of depth values according to the data obtained from the specific period (year 2019), further from the data of the Czech Hydrometeorological Institute and also from the data of the digital landscape model DMU25. At present, depth values are not relevant in DMU25. Another contribution of the article is the definition of depth values to the limit values of selected vehicles in the Army of the Czech Republic and their possibilities of fording, as well as the proposal of updating and optimization depth values for the developed application software.
\end{abstract}

\section{Keywords:}

depth of wet gap, digital landscape model, engineer support, stream-gauging station

\section{Introduction}

The depth of wet gap is a criterion that affects the fording of vehicles, underwater driving and the establishment of transport points [1-3]. This means the possibility of wet gap crossing, because vehicles are limited by their technical values. It applies especially to shallow or deep fording, underwater driving or the establishment of bridge platforms. Some vehicles have bridges for which a minimum and maximum installation depth can be determined. Accurate data of the depth of wet gaps are used

\footnotetext{
* Department of Engineer Support, Faculty of Military Leadership, University of Defence in Brno, Kounicova 156/65, CZ-662 10, Brno, Czech Republic. Phone: +4206032627 15, E-mail: martin.sedlacek@unob.cz.ORCID 0000-0002-4999-7871.
} 
for the planning process of the Task Force staff, in which the variants of wet gap crossing are analyzed, calculated and processed. The mentioned variations may be based on the use of forces and means in the operational area, but also on the section where the wet gap will be crossed [4]. Military geography defines watercourses and water surfaces as water obstacles [5-7]. Wet gap/water crossing expression is defined in military engineering. That means a part of the attack with crossing a water obstacle by troops (Fig. 1). With regard to the circumstances, it is divided into hasty crossing and deliberate crossing. The troops cross wet gaps by fording, deep fording, driving tanks under water, sailing on amphibious combat vehicles, vessels, ferries and bridges [8].



Fig. 1 The sample of wet gap crossing [9]

The depth of the watercourses varies in both the transverse and longitudinal profiles and is subject to more time changes than the water obstacles of still waters. The depth of water obstacles varies depending on the degree of hydrological and hydraulic transformation [10].

The Geographic Service of the Army of Czech Republic (GeoSl ACR) manages various geographic databases and provides geographic support to the ACR forces. The digital landscape model DMU25 is suitable as a source of geographic information for the assessment of wet gap crossing. DMU25 can be understood as vector data covering the territory of the Czech Republic and its surroundings. DMU25 contains several thematic layers, some of which contain information on the profile characteristics of the watercourse and the characteristics of the water surface. It is a hydrographic depth (HDP) attribute that represents the depth of a water obstacle [11]. In order to assess the relevance of the depth values in DMU25, a comparison has been made with the results of continuous measurement of stream-gauging stations from the measured period (2019) from the joint-stock company Morava River, and the Czech Hydrometeorological Institute (CHMI). For this purpose, 10 stream-gauging stations are identified in Chapter 2. The values from the measured period also specify the possibilities of fording in the conditions of the ACR with selected military vehicles and means on selected water obstacles. 
Chapter 2 uses the scientific method of classification analysis to classify values into groups and functional analysis to describe the links between river depth and technical characteristics of ACR means in wet gap crossing military operations, as well as synthesis to clarify and include the issue in the staff planning process and measurement as a basic collection method. The Chapter 3 uses the method of incomplete induction to design the optimization of water obstacle depth values.

In Chapter 3, a proposal is made to update and optimize the values of the depths of water obstacles in order to implement them in the developed application software for wet gap crossing (APV PVP). Its use is assumed for the ACR Land Forces. The abbreviation APV PVP is based on the Czech designation for project of "Application Software for wet gap crossing in the ACR".

\section{Average Annual Depths of Selected Stream-Gauging Stations}

The selection of stream-gauging stations was based on the identification of the largest rivers in the territory of Moravia [12]. These are the rivers Morava, Jihlava, Svratka and Dyje. The stream-gauging stations are located in various mileage of the river profile [13] and have been chosen in such a way as to preserve the diversity of the location on the river and also in the territory of Moravia. The selection also takes into account that the stream-gauging stations are not usually located just in front of the dam or weir in the direction of the river stream, so that the depth values in the profiles are not distorted.

Tab. 1 compares the average annual depth of rivers in stream-gauging stations that were collected in the period from January 24, 2019 to January 28, 2020 with the values from CHMI.

Tab. 1 Comparison of average annual depth of rivers

\begin{tabular}{|c|c|c|c|c|c|}
\hline Stream-gauging station & River & $\begin{array}{c}\text { Mileage }^{1} \\
{[\mathrm{~km}]}\end{array}$ & $\begin{array}{c}\text { Distance }^{2} \\
{[\mathrm{~m}]}\end{array}$ & $\begin{array}{c}\text { Depth }^{3} \\
{[\mathrm{~cm}]}\end{array}$ & $\begin{array}{c}\text { Depth } \\
\text { CHMI }^{4}\end{array}$ \\
\hline Moravičany (1) & Morava & 272.80 & 10 & 92.2 & 108 \\
\hline Olomouc (2) & Morava & 232.30 & 6200 & 113.2 & 137 \\
\hline Kroměřížž (3) & Morava & 180.21 & 13100 & 154.2 & 187 \\
\hline Spytihněv (4) & Morava & 157.06 & 12200 & 121.0 & 164 \\
\hline Strážnice (5) & Morava & 121.67 & 19700 & 146.7 & 181 \\
\hline Ptáčov (6) & Jihlava & 88.24 & 3000 & 80.1 & 96 \\
\hline Ivančice (7) & Jihlava & 32.95 & 5700 & 119.6 & 134 \\
\hline Veverská Bítýška (8) & Svratka & 66.72 & 1800 & 127.8 & 151 \\
\hline Dalečín (9) & Svratka & 118.01 & 8700 & 56.9 & 74 \\
\hline Travní Dvůr (10) & Dyje & 74.80 & 2600 & 83.5 & 115 \\
\hline \multicolumn{6}{|c|}{$\begin{array}{l}{ }^{1} \text { - Mileage of the river profile. } \\
2 \text { - Distance to the next weir/dam. } \\
{ }^{3} \text { - Average annual depth by measurement of stream-gauging stations in } 2019 . \\
{ }^{4}-\text { Average annual depth according to CHMI [cm]. This is the long-term average annual } \\
\quad \text { depth for the reference period 1981-2010. }\end{array}$} \\
\hline
\end{tabular}


Fig. 2 shows the location of the analyzed rivers and stream-gauging stations. Locations of stream-gauging stations are identical with locations of HDP attributes in DMU25.

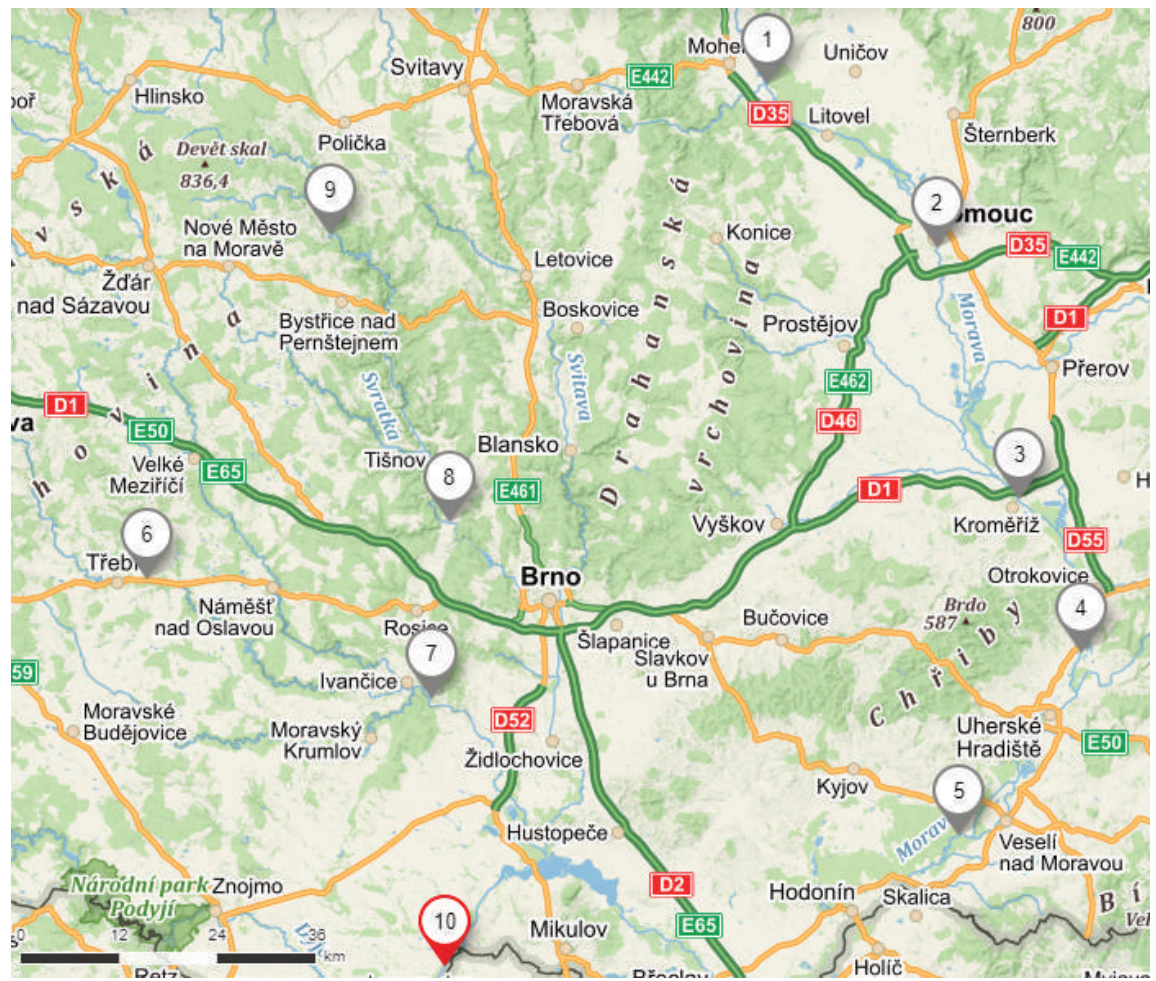

Fig. 2 Location of analyzed rivers and stream-gauging station

Tab. 1 shows that at all selected stream-gauging stations, the measured average annual depth is lower than the determined long-term average annual depth according to CHMI. This is due to lower rainfall and prolonged drought since 2014, resulting in lower values than in the long-term average [3]. This is expressed in Tab. 2 showing lower average annual flow rates affecting the depth of rivers.

Tab. 2 Average annual flow rate versus long-term average annual flow from 1981-2010 [\%]

\begin{tabular}{|c|c|c|c|c|c|}
\cline { 2 - 5 } \multicolumn{1}{c|}{} & $\mathbf{2 0 1 4}$ & $\mathbf{2 0 1 5}$ & $\mathbf{2 0 1 6}$ & $\mathbf{2 0 1 7}$ & $\mathbf{2 0 1 8}$ \\
\hline Moravičany & 63 & 68 & 60 & 73 & 58 \\
\hline Olomouc & 64 & 73 & 69 & 72 & 59 \\
\hline Kroměř́̌z & 70 & 66 & 66 & 69 & 49 \\
\hline Strážnice & 69 & 65 & 64 & 66 & 44 \\
\hline Ptáčov & 73 & 67 & 57 & 51 & 48 \\
\hline Ivančice & 79 & 70 & 57 & 36 & 40 \\
\hline Veverská Bítýška & 70 & 76 & 64 & 48 & 41 \\
\hline Travní Dvůr & 69 & 67 & 63 & 40 & 29 \\
\hline
\end{tabular}


Tab. 2 does not assess the Spytihněv and Dalečín stream-gauging stations due to their absence in the document Hydrological Balance of Water Quantity and Quality in the Czech Republic. The assessment of 2019 was not published by March 2020, but below-average annual flow rates can be expected as in previous years.

The DMU25 shows the values of depth at the so-called intermediate depth (at the average depth in the summer months) and therefore Tab. 3 compares the measured depth at stream-gauging stations in the summer months (June-August) with values according to DMU25. The average state in the summer months also applies to the current speed in DMU25.

Tab. 3 Comparison of average summer depths of rivers

\begin{tabular}{|c|c|c|}
\hline $\begin{array}{l}\text { Stream-gauging sta- } \\
\text { tion }\end{array}$ & $\begin{array}{c}\text { Depth }^{1} \\
{[\mathrm{~cm}]}\end{array}$ & $\begin{array}{l}\text { Depth DMU252 } \\
{[\mathrm{cm}]}\end{array}$ \\
\hline Moravičany & 84.8 & 150.0 \\
\hline Olomouc & 92.0 & 180.0 \\
\hline Kroměříž & 135.1 & 300.0 \\
\hline Spytihněv & 100.1 & 240.0 \\
\hline Strážnice & 117.3 & 350.0 \\
\hline Ptáčov & 61.4 & 120.0 \\
\hline Ivančice & 115.6 & 70.0 \\
\hline Veverská Bítýška & 132.3 & 100.0 \\
\hline Dalečín & 52.3 & 40.0 \\
\hline Travní Dvůr & 93.2 & 100.0 \\
\hline \multicolumn{3}{|c|}{$\begin{array}{l}1 \text { - Measured average depth at stream-gauging stations in the summer months (6-8). } \\
2 \text { - Average depth according to DMU25. }\end{array}$} \\
\hline
\end{tabular}

It can be seen from Tab. 3 that the values of the measured average summer state differ significantly from the values of the average state according to DMU25.

Values of average depth in summer months (June to August) may be higher than average annual depth due to low snow cover and unchanged flow rate in spring or due to torrential or long-term rainfall in summer. The fact at the stream-gauging station in Veverská Bítýška and Travní Dvůr, where the values for the summer months are higher, confirms this assumption. This is due to prolonged drought in the autumn and winter months.

In Fig. 3, it is possible to identify the measured depth on a specific day of the month. Fig. 3 also shows the months in which the depth was the highest during the period under review. The graph is not continuous due to missing data. The number of days measured differs due to the update, availability and display of data from CHMI.

The depth of the water obstacle must be taken into account both in planning and in the actual implementation of wet gap crossing. This is a criterion that is regulated by the Defence Standardisation, Codification, and Government Quality Assurance Authority [14] and it is particularly relevant to the limit values for fording (shallow and deep) and underwater driving of current means introduced in the ACR, as well as for solved modernization projects (e.g. acquisition of a new infantry combat vehicle, PBVP). 
Furthermore, the number of days in the measured period is defined, when the depth of the water obstacle at the stream-gauging stations is higher than the limit value for selected ACR means. This results in the selection of means to cross the water obstacle at the site, whether in terms of impossibility of fording or underwater driving, but also in terms of the establishment of bridge platforms by forces and means of the Army Corps of Engineers.

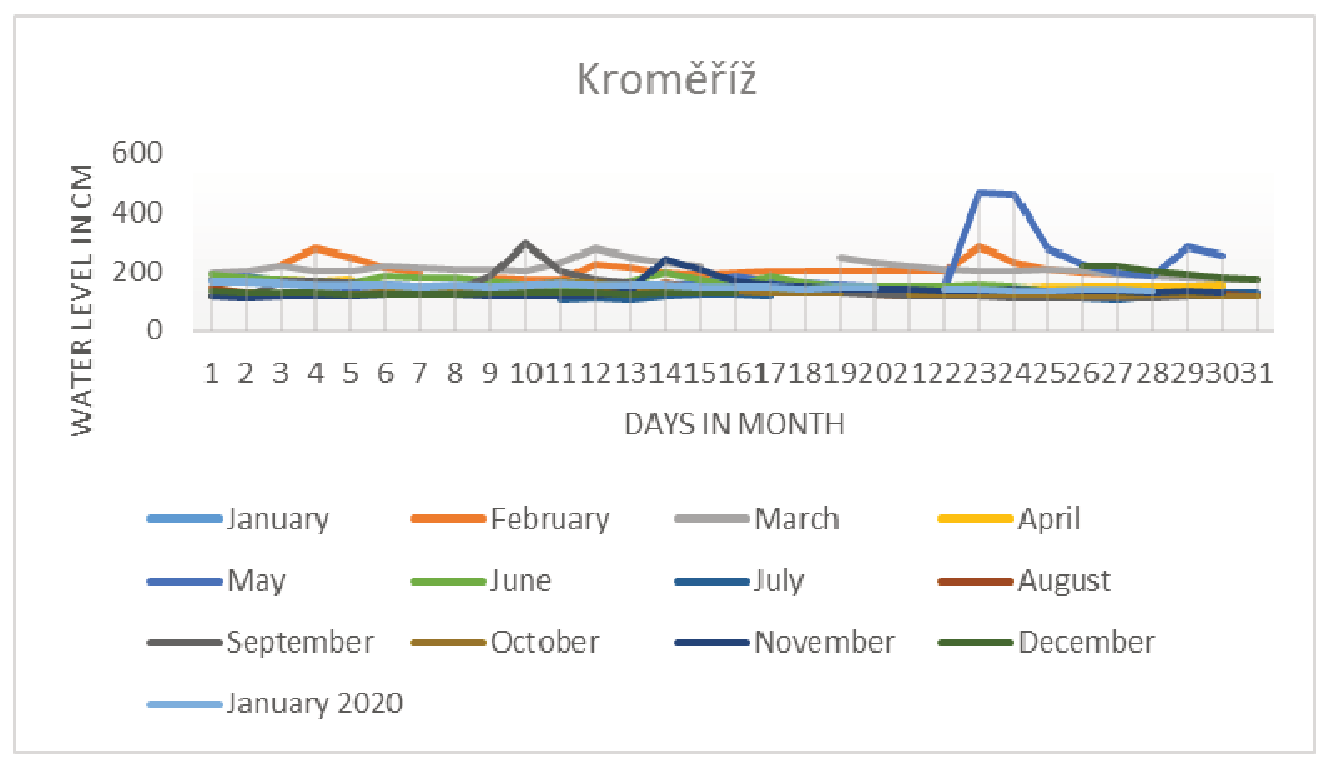

Fig. 3 Daily depth in profile of stream-gauging station Kroměř́žz

Tabs 4 and 5 define the fording values of selected ACR vehicles. The principle of selection is based on the assumption of their use for wet gap crossing, the most widespread representation in the ACR and the requirement of a modernization project that will result in a significant number of means in the ACR (Figs 4 and 5) [15].

Tab. 4 Selected ACR means of Corps of Engineers for wet gap crossing [16]

\begin{tabular}{|c|c|c|c|c|c|}
\cline { 2 - 6 } \multicolumn{1}{c|}{} & \multicolumn{5}{c|}{ Means of Corps of Engineers for wet gap crossing } \\
\hline $\begin{array}{c}\text { Limit criteria } \\
\text { and their values } \\
\text { (No. in Fig. 4) }\end{array}$ & AM-50 & PMS & PTS-10 & MT-55 & PM-55 \\
\hline Fording [cm] & 140 & 140 & float & 120 & (5) \\
\hline
\end{tabular}

Tab. 5 Other selected means of ACR for wet gap crossing [16]

\begin{tabular}{|c|c|c|c|c|c|c|}
\hline & \multicolumn{6}{|c|}{ Other selected means of ACR for wet gap crossing } \\
\hline $\begin{array}{l}\text { Limit criteria } \\
\text { and their } \\
\text { values } \\
\text { (No. in Fig. 5) }\end{array}$ & $\begin{array}{c}\text { T-72 } \\
\text { M4CZ } \\
\text { (6) }\end{array}$ & BVP-2 & $\begin{array}{c}\text { KBVP } \\
\text { Pandur II } \\
\text { (8) }\end{array}$ & $\begin{array}{c}\mathrm{T}-815 \\
(8 \times 8) \\
(9)\end{array}$ & $\mathrm{T}-810$ & $\begin{array}{c}\text { PBVP } \\
\text { substitute of } \\
\text { BVP-2 } \\
\text { (11) }\end{array}$ \\
\hline Fording $[\mathrm{cm}]$ & 120 & float & 140 & 140 & 120 & 120 \\
\hline
\end{tabular}


The minimum fording depth of selected engineer and other means is $120 \mathrm{~cm}$, but some means meet with a fording depth value of $140 \mathrm{~cm}$ (Tabs 4 and 5). Means PTS-10 and BVP-2 have the ability to float. BVP-2 stops fording and begins to float from a depth of $150 \mathrm{~cm}$ and $180 \mathrm{~cm}$ is set for PTS-10. The modernization project for shallow fording for the new PBVP is set at a minimum of $120 \mathrm{~cm}$. Deep fording and underwater driving are already excluded from the specification of "Tactical-technical requirements for a new infantry fighting vehicle and its modifications" [17]. The value of the minimum required fording depth for shallow fording is set by the Defence Standardisation, Codification, and Government Quality Assurance Authority [5] at $100 \mathrm{~cm}$ and the selected ACR engineer and other means (Tabs 4 and 5) meet it.

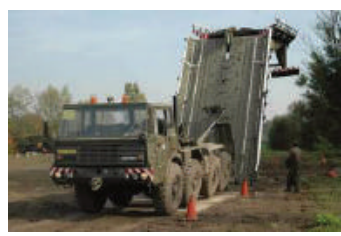

(1)



$(2)$


(3)

(4)

Fig. 4 Selected ACR means of Corps of Engineers for wet gap crossing [16]

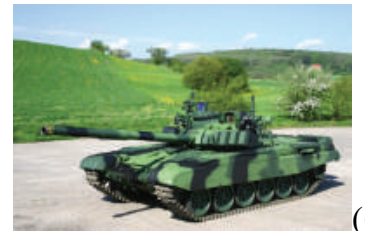

(6)
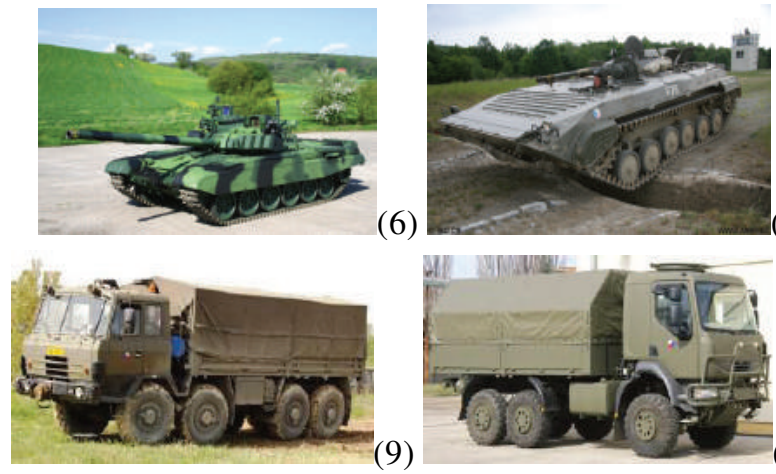

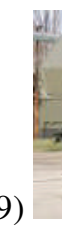

(7)

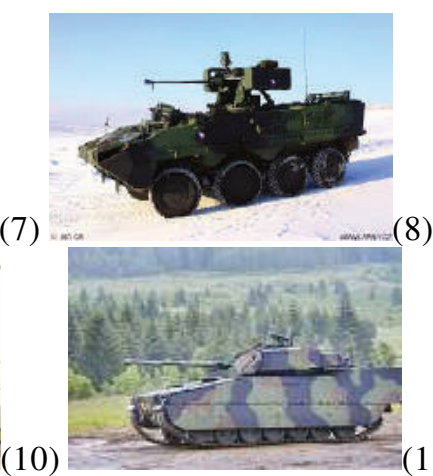

Fig. 5 Other selected means of ACR for wet gap crossing [16]

The depth of the obstacle in the profile of the stream-gauging stations is compared with the limit fording depth values of the ACR means, i.e. to $120 \mathrm{~cm}$ and $140 \mathrm{~cm}$. These values are considered assuming a bearing bottom (stone, gravel or concrete road parts). The unbearable bottom (sandy, muddy), on which vehicles are usually bogged down, is not evaluated [18]. It is then necessary to subtract the height of the bogging from the depth in order to meet the vehicle limit values.

Tab. 6 shows the number of days for which the water obstacle value in the profile of the stream-gauging station was higher than or equal to $120 \mathrm{~cm}$ and further greater than or equal to $140 \mathrm{~cm}$. The days with a measured depth higher than or equal to $140 \mathrm{~cm}$ are also included in the days with a measured depth higher than or equal to 
$120 \mathrm{~cm}$. The number of days measured differs due to the update, availability and display of data from CHMI.

Tab. 7 builds on the previous Tab. 6 and determines the number of days within the measured period in which it is possible to use shallow fording in a given profile of a stream-gauging station for wet gap crossing. At the same time, it determines the percentage usability of the selected ACR means within the measured period.

Tab. 6 Number of days above fording limits of means

\begin{tabular}{|c|c|c|c|c|}
\hline & $\begin{array}{l}\text { Number of days } \\
\text { with depth } \\
\geq 120 \mathrm{~cm} \\
\end{array}$ & $\begin{array}{c}\text { Number of days } \\
\text { with depth } \\
\geq 140 \mathrm{~cm} \\
\end{array}$ & \begin{tabular}{|c|} 
Number of \\
measured \\
days
\end{tabular} & $\begin{array}{c}\operatorname{Depth}^{1} \\
{[\mathrm{~cm}]}\end{array}$ \\
\hline Moravičany & 26 & 8 & 320 & 92.2 \\
\hline Olomouc & 106 & 67 & 322 & 113.2 \\
\hline Kroměříž & 286 & 188 & 322 & 154.2 \\
\hline Spytihněv & 82 & 58 & 279 & 121.0 \\
\hline Strážnice & 197 & 112 & 323 & 146.7 \\
\hline Ptáčov & 39 & 17 & 322 & 80.1 \\
\hline Ivančice & 110 & 34 & 322 & 119.6 \\
\hline Veverská Bítýška & 223 & 40 & 281 & 127.8 \\
\hline Dalečín & 1 & 0 & 280 & 56.9 \\
\hline Travní Dvůr & 23 & 7 & 278 & 83.5 \\
\hline
\end{tabular}

Tab. 7 Applicability of selected means within profiles of stream-gauging stations

\begin{tabular}{|c|c|c|c|c|c|}
\cline { 2 - 6 } \multicolumn{1}{c|}{} & $\begin{array}{c}\text { Number of } \\
\text { days }\end{array}$ & $\begin{array}{c}\text { Usability } \\
{[\%]}\end{array}$ & $\begin{array}{c}\text { Number of } \\
\text { days }^{\mathbf{2}}\end{array}$ & $\begin{array}{c}\text { Usability } \\
{[\%]}\end{array}$ & $\begin{array}{c}\text { Number of } \\
\text { measured days }\end{array}$ \\
\hline Moravičany & 294 & 91.9 & 312 & 97.5 & 320 \\
\hline Olomouc & 216 & 67.1 & 255 & 79.2 & 322 \\
\hline Kroměříz & 36 & 11.1 & 134 & 41.6 & 322 \\
\hline Spytihněv & 197 & 70.6 & 221 & 79.2 & 279 \\
\hline Strážnice & 126 & 39.0 & 211 & 65.3 & 323 \\
\hline Ptáčov & 283 & 87.9 & 305 & 94.7 & 322 \\
\hline Ivančice & 212 & 65.8 & 288 & 89.4 & 322 \\
\hline $\begin{array}{c}\text { Veverská } \\
\text { Bítýška }\end{array}$ & 58 & 20.6 & 241 & 85.8 & 281 \\
\hline Dalečín & 279 & 99.6 & 280 & 100 & 280 \\
\hline Travní Dvůr & 255 & 91.7 & 271 & 97.5 & 278 \\
\hline $\begin{array}{l}1 \\
2\end{array}$ - Applicability of means with fording up to $120 \mathrm{~cm}$ in days. \\
\hline
\end{tabular}

Tab. 7 takes into account only one criterion, namely the depth of the water obstacle. However, in order to cross a wet gap, it is necessary to evaluate additional criteria for individual crossing options (shallow fording, etc.). From the point of view of natu- 
ral or artificial environment, this can also be the speed of flow, width of water obstacle, bank slope, vertical obstacle height and others $[19,20]$. However, these are not further investigated in this article.

The number of usable days is determined by the applicability of means with different fording limit values. This evaluation allows to predict the possibility of fording as a usable variant of wet gap crossing in ACR conditions. It can be assumed, for example, that the profile of the Dalečín stream-gauging station will always be suitable from the point of view of the depth of the river for all selected ACR means, while the profile of the Kroměříž stream-gauging station will have to be judged according to available means and other characteristics.

\section{Implementation of Watercourse Depth Modelled Values into Applica- tion Software for Wet Gap Crossing}

A characteristic feature of a water obstacle is its depth. Depth information can be gathered and collected in the ACR during the planning process of the Task Force staff, where water obstacles are usually analyzed and evaluated, or when new maps (usually digital) are created or updated. The way of obtaining information on a water obstacle can be based on reconnaissance, intelligence, evaluating products (databases) or even questioning the local population or intuition. Further only the databases are solved.

The project "Application Software for wet gap crossing in the ACR" (APV PVP) is currently under development. APV PVP is based on the principle of usability of geographic databases (DMU25 was chosen based on the analysis) and an algorithm has been created for this purpose. It aims to take into account the capabilities of its own forces and means in the operational area with respect to the data from the DMU25 related to the water obstacle and the surrounding area and to propose, based on data evaluation, a suitable section for wet gap crossing. Relevant and up-to-date data are essential for correct evaluation.

Data on the depth of the watercourse can be obtained within the DMU25 from the thematic layer WATER and COMMUNICATION, individual types of objects and the attribute HDP (depth), which records the values in the given place in meters. As already mentioned, the values are based on the average depth in summer months, which is not suitable for the application in the project. According to the measured values during the measured period it is possible to divide the depth into individual days, which would be extensive in terms of data intensity and inaccurate in the future for next years.

Based on the depth values in DMU25, a proposal for the implementation of average monthly values into HDP attributes has been chosen. In the given attribute, the values are updated from the CHMI data and from the measured period (1/20191/2020). The measured state in January 2019 and 2020 creates an arithmetic mean. The proposal has been based on the values of depth in 10 stream-gauging stations during the measured period and CHMI data. These have been recalculated for all intermediate points on the watercourse with the HDP attribute. However, conversion constants for individual months are intentionally not disclosed. Eqs (1) and (2) specify the procedure for calculating the depth of a given water profile. These calculations apply to flowing water obstacles.

$$
Z_{i}=\frac{\phi h_{i}}{\phi H} k_{i}
$$


where

$i=1, \ldots, 12$ represent the month,

$Z_{i}$ - the depth conversion factor from the measured values,

$\emptyset h_{\mathrm{i}}-$ the measured average depth in a given month from 10 stream-gauging stations,

$\emptyset H$ - the measured average annual water depth from 10 stream-gauging stations stations,

$k_{i}-$ the conversion constant for individual months.

$$
h=h_{\mathrm{chmi}} Z_{i}
$$

$h$ - the depth of water profile taking into account the CHMI data and measured values, $h_{\text {chmi }}$ - the depth of water profile according to the CHMI data.

As part of the APV PVP project, it is necessary to update the values of river depths from the CHMI in DMU25 and then to program the conversion for all points with the HDP attribute with the possibility of displaying it in individual months, as shown in Fig. 6. The HDP attribute is valid only in the WATER and COMMUNICATION layers. For other obstacles and depth recording, the depth (DEP) attribute is used. The calculated data will be purposefully used only in APV PVP and DMU25 database will not be changed or updated.

By identifying average monthly values, the Task Force staff can take into account more accurate information in the planning process of the operation. The form of the attribute table entry is as follows:



Fig. 6 Recording the depth of an obstacle with HDP attributes

The HDP attribute in Fig. 6 represents the average annual state, while other attributes of HDP 1-12 express the average monthly state according to the given calendar month. From Fig. 6 it is also possible to identify other attributes belonging to the object. The values of the attributes are only approximate and do not follow from the real state of the measured values even according to the CHMI.

Within the APV PVP, the user has the possibility to report the depth of water obstacle manually. Then the calculations take into account the depth of water obstacle set by the user. This option is offered due to more accurate data that can be obtained from the reconnaissance (e.g. using modern technologies like echo sounder or underwater drones). However, a member of staff has always the option to change this decision and to proceed.

Another solution related to the depth of the water obstacles is the interconnection with the current velocity. This is another criterion that affects fording, the establishment of bridge platforms and the underwater platform (underwater tank driving). 


\section{Conclusion}

The depth of water obstacles is a criterion that influences the maneuverability of troops when conducting a military operation. It can be assumed that the permanent bridges of roads will be disrupted, destroyed or defended by the enemy as part of combat operations, and the importance of establishment of the individual sites across a water obstacle will increase. The selection and establishment of some transport sites depends, inter alia, on information about the water obstacle.

Information about the water obstacle for military purposes in the Czech Republic can be obtained from DMU25, but these are not currently accurate. Another possibility of obtaining information is CHMI data, which, however, only take into account the annual average (compiled from values from 1981 to 2010). However, since 2014, owing to a prolonged drought, the flow rates in rivers have been reduced, usually by 25-30\% (Tab. 2), and this has an impact on depth of water obstacles (Tab. 1). A similar trend can be expected in the next years.

Based on the values from the measured period, the average annual depths at 10 points (Tab. 1), where the stream-gauging stations are located, are compared. Data from the measured period also make it possible to calculate the values of average monthly depths. This clarifies the proposals for area selection and how to cross wet gap. The depth of the water obstacle has a limiting effect on military means. These are limited by their values for fording, if they do not have the ability to float or otherwise. Possibilities of utilization of fording of selected ACR means with respect to variable depth of water obstacles are described in Tabs 6 and 7.

To tackle water obstacles, the Task Force staff in the planning process needs sufficient data and information of the obstacles. These will be provided to them by an engineer officer who can use APV PVP. The values have been taken from both the measured and the CHMI data. They are based on mutual comparison and recalculation according to the coefficient $\mathrm{Z}_{i}$ (Eqs (1) and (2)). The values are in the HDP attribute table, which is adjusted for individual months of the year.

\section{Acknowledgement}

This work was conducted within the framework of the specific university research projects SV19-FVL-K108-SED, SV21-K-210 managed by the University of Defence in Brno, defence research intentions DZRO FVT 3 VAROPS and NATO - STO Support Project CZE-AVT-2019.

\section{References}

[1] HOSLER, D.J. Gap-Crossing Operations: Medieval and Modern. Military Review [online]. March-April 2020. [viewed 2020-08-30]. Available from: https://www.armyupress.army.mil/Journals/Military-Review/English-EditionArchives/March-April-2020/Hosler-Gap-Crossing/

[2] GRAU, W.L. Snorkeling Russian Tanks Across Rivers. Armor [online]. 2019. [viewed 2020-07-27]. Available from: https://www.benning.army.mil/ armor/earmor/content/issues/2019/Fall/4Grau19.pdf

[3] Crossing the Gap Safely: Vehicle Safety [online]. July 2019. [viewed 2020-0715]. Available from: https://www.army.mil/article/224642/crossing_the_gap _safely_vehicle_safety 
[4] ROLENEC, O., K. ŠILINGER, T. PALASIEWICZ and P. ŽIŽKA. Supporting the Decision-Making Process in the Planning and Controlling of Engineer Task Teams to Support Mobility in a Combat Operation. International Journal of Education and Information Technologies, 2019, 13, pp. 33-40. ISSN 2074-1316.

[5] LAUERMANN, L. and M. RYBANSKÝ. Military Geography (in Czech). Prague: Ministry of Defence of the Czech Republic, 2002. ISBN 80-238-9274-6.

[6] CALDWELL, D.R., J. EHLEN and R.S. HARMON. Studies in Military Geography and Geology. Boston: Springer, 2004. ISBN 978-1-4020-3105-2.

[7] BRINIUK, N.IU, E.L. KORSHUNOV and A.A. MIKHAĬLOV. Military Geography and Military Statistics: History and Present (in Russian). Sankt-Peterburg: Dmitriı̌ Bulanin, 2018. ISBN 978-5-86007879-6.

[8] AAP-6. NATO Glossary of Terms and Definitions. NATO Standardization Office, 2019.

[9] Generals of Three Nato Countries Train the Forced Crossing of the Water Barrier in Litoměrice (in Czech) [online]. [viewed 2020-08-31]. Available from: http://www.acr.army.cz/scripts/detail.php?id=136818\&tmplid=527

[10] RYBANSKÝ, M., M. HUBÁČEK, P. ZERZÁN, F. DOHNAL and M. BUREŠ. Analysis of the Impact of Terrain Surface, Soils, Hydrology and Vegetation on the Cross-Country Movement (in Czech) [Final Report]. Brno: University of Defence in Brno, 2017.

[11] Catalog of Topographic Objects (in Czech). Military Topographic Institute in Dobruška, 2007.

[12] Hydrological Balance of Water Quantity and Quality in the Czech Republic (in Czech) [online]. Czech Hydrometeorological Institute. [viewed: 2020-4-2]. Available from: http://voda.chmi.cz/opzv/bilance/bilance.htm

[13] Hydrological Situation (in Czech) [online]. Czech Hydrometeorological Institute. [viewed: 2020-03-11]. Available from: http://portal.chmi.cz/aktualnisituace/hydrologicka-situace/hydrologicka-situace

[14] Fording and Floating of Military Vehicles. General Requirements (in Czech). Defence Standardisation, Codification, and Government Quality Assurance Authority. Prague, 2017. ČOS 230501.

[15] CIBUlOVÁ, K., O. ROLENEC and V. GARBA. A Selection of Mobility Support Engineering Devices of NATO Armies Usable in the Czech Armed Forces Combat Operations. In: Proceedings of the International Conference of Military Technologies. Brno: IEEE, 2019. DOI 10.1109/MILTECHS.2019.8870016.

[16] Technology and Armament (in Czech) [online] [viewed: 2020-10-23]. Available from: http://www.acr.army.cz/technika/default.htm

[17] Tactical and Technical Requirements for a New Infantry Fighting Vehicle and its Modifications (in Czech). Ministry of Defence of the Czech Republic, 2018. Attachment no. 1.

[18] RYBANSKÝ, M. and F. DOHNAL. The Possibilities of Determination of Watercourse Passability by Military Vehicles Using Geographical Data (in Czech). In: Proceedings of the $23^{\text {rd }}$ Cartographic Conference. Prague: Czech Technical University in Prague, 2019, pp. 49-49. ISBN 978-80-01-06639-3. 
[19] DOHNAL, F., M. RYBANSKÝ and M. HUBÁČEK. Water Regime of Rivers and Its Impact on Cross-Country Mobility. In: Proceedings of the $19^{\text {th }}$ International \& $14^{\text {th }}$ European-African Regional Conference of the International Society for Terrain-Vehicle Systems. Budapest: Szent Istvan University, 2017, pp. 1-2. ISBN 978-963-269-669-0.

[20] DOHNAL, F., M. RYBANSKÝ and K. ŠIMKOVÁ. Water Regime and Prediction of Its Impact on River Crossing in Different Types of Zonal Landscape. In: Proceedings of the $25^{\text {th }}$ Central European Geological Conference: Useful Geography: Transfer from Research to Practice. Brno: Masaryk University, 2018. ISBN 978-80-210-8907-5. 